\title{
Pallavi Aiyar, Smoke and Mirrors: An Experience of China
}

N. Jayaram

\section{(2) OpenEdition}

\section{Journals}

Electronic version

URL: http://journals.openedition.org/chinaperspectives/5085

DOI: 10.4000/chinaperspectives.5085

ISSN: 1996-4617

\section{Publisher}

Centre d'étude français sur la Chine contemporaine

Printed version

Date of publication: 21 April 2010

ISSN: 2070-3449

\section{Electronic reference}

N. Jayaram, «Pallavi Aiyar, Smoke and Mirrors: An Experience of China », China Perspectives [Online], 2010/1 | 2010, Online since 22 April 2010, connection on 21 September 2020. URL : http://

journals.openedition.org/chinaperspectives/5085 ; DOI : https://doi.org/10.4000/chinaperspectives. 5085

This text was automatically generated on 21 September 2020

(c) All rights reserved 


\title{
Pallavi Aiyar, Smoke and Mirrors: An Experience of China
}

\author{
N. Jayaram
}

Pallavi Aiyar, Smoke and Mirrors: An Experience of China, New Delhi, Fourth Estate, 2008, 274 pp.

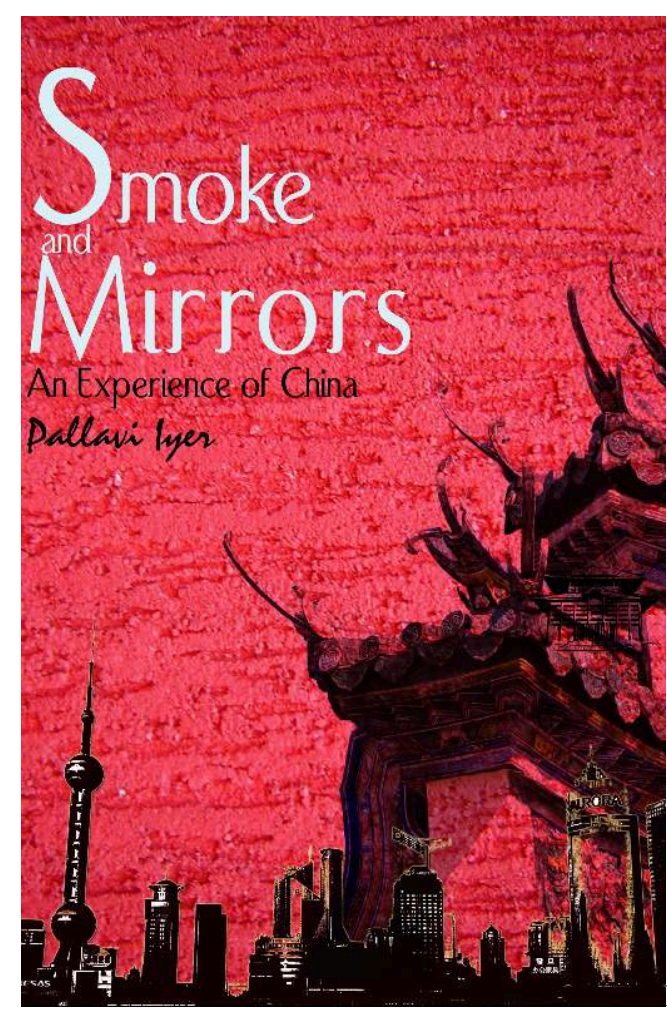

Pallavi Aiyar's book, a combination of memoirs, journalistic reportage, and travelogue, is valuable for two reasons. Firstly, there is a great dearth in India of writing on China. As these two countries have the largest populations in the world, as well as being geographical neighbours with ancient civilisations and tense relations over the past half a century, this is a highly untenable situation. Although a number of Indians have focused on China's foreign and defence 
policies - and in recent years on its economic prowess - few have spent enough time in the country to reflect intelligently on aspects of life there. Vikram Seth, the celebrated Indian writer and poet, is one of the few to have done so. His 1982 book, From Heaven Lake: Travels Through Sinkiang and Tibet, gave a fascinating account of China at the start of the 1980s. Seth did not confine his observations to Tibet and Xinjiang as suggested by the title, but provided vignettes of China as it was then, from a liberal Indian perspective. Aiyar's book, published nearly three decades later, may have drawn some inspiration from Seth's example. In fact, Aiyar admits to having been interested in Seth's work since her teens.

2 Secondly, Aiyar's book provides a highly sensitive look at China; she is circumspect in her remarks on all that economic development has wrought there, particularly on religious rights and human rights in general, and on the rhythm of daily life as she perceived it. She acknowledges at the end that her book is full of considerations "on the one hand" juxtaposed with those "on the other," but it is in fact this nuanced treatment, her caution and hesitation to arrive at pat judgments, that gives her book weight. She constantly compares China with India, sparing neither their abject failings. Her scrupulous attention to considering every issue from many angles precludes categorical conclusions.

3 Aiyar tackles one question at length: "If I could choose, would I rather be born Indian or Chinese?" (p. 243), and her preliminary conclusion is uncannily similar to that of Seth nearly three decades ${ }^{1}$ ago and of Aravind Adiga, a prize-winning author, in 2008. ${ }^{2}$ She says "...were I to be able to ensure being born even moderately well-off, I would probably plump for India over China. ... On the other hand, were I to be born poor, I would take my chances in authoritarian China, where despite lacking a vote, the likelihood of my being decently fed, clothed and housed [is] considerably higher. Most crucially, China would present me with relatively greater opportunities for upward social mobility." But the argument hardly ends there for Aiyar. Indians can use their vote to hold up infrastructure projects that entail wanton destruction of their habitats, but the Chinese regime is "adept at disabling the capacity of disaffected peoples to organize, thus depriving them of the influence of numbers that could pressure government policy..." (p. 244). And yet, the right to vote in India "did not necessarily or even usually translate into better governance." Voters periodically throw out governments, but that achieves little. Thus, while the Chinese regime "derived its legitimacy from delivering growth, in India a government derived its legitimacy simply from its having been voted in" (p. 255). This is an example of the many chains of argument and counter-argument with which the book is laced.

Perhaps the book's piece de resistance consists of Aiyar's reflections on China's attitude towards religion and towards Tibet, which she visited, travelling on the first train from Beijing to Lhasa, on 1 July 2006. She is scathing in her observations on the Chinese regime's unimaginative stranglehold on Muslims and Tibetan Buddhists and its fear of diversity. In these chapters, she feels less compelled to compare India unfavourably with China. Although mindful of the growth of Hindu fanaticism and events such as the destruction of a mosque in northern India in 1992, the massacre of Sikhs in 1984 after the assassination of prime minister Indira Gandhi by her Sikh bodyguards, and the antiMuslim pogrom in Gujarat state in 2002, she takes a dim view of the Chinese regime's emphasis on "harmony" manifested by an all-enveloping repression against religious practitioners and ethnic minorities. Unlike China, India accepts its diversity and affords 
greater leeway for its minorities. In a discussion of the neglect of north-eastern India and its peoples, she says: "India had not provided the Nagas, Mizos and others in the (north-eastern) region with the broad roads or tourism dollars that China ensured for its border provinces but New Delhi did provide something else: cultural freedom" (p. 234).

5 Aiyar acknowledges that many of the "stories," as she calls them, in this collection began as reports she wrote for one of India's better-quality newspapers, The Hindu. Under its current editor, N. Ram, the English-language newspaper has become trenchantly pro-Beijing. This meant Aiyar's reports in The Hindu had to keep to a narrow ledge, avoiding overt criticism of China while conveying an accurate picture of what she saw and heard. Amazingly, she pulled off the feat with credit, even winning an Indian prize for political reporting. ${ }^{3}$ A campaigning group, Friends of Tibet, initially failed to appreciate the quality of Aiyar's reporting, the care with which she walked the tightrope in presenting a dispassionate account of what she saw in China and Tibet while ensuring that her writing would get past her editor's pro-China blinkers. They criticised her on their website, ${ }^{4}$ but have since privately apologised to her. ${ }^{5}$

6 The book contains lively accounts of life in one of Beijing's remaining hutongs, where the author found comfortable lodgings and observed the changes wrought by developments linked to the Beijing Olympics. She deals at length with the widespread destruction going on around the capital, with ordinary citizens unable to resist the bulldozers. (A gritty and detailed account of the process is available in the excellent book by Michael Meyer devoted to the subject. $)^{6}$

7 Aiyar compares what she observes with her experience of India, the feeling of egalitarianism and "dignity of labour" in China contrasted with the class and caste divisions of India, the place of education, and the status of women. She is particularly astute in her observations on the condition of women, their presence in the workforce and their status in Chinese society. Needless to say, India fares extremely poorly in its treatment of women. She prefers Beijing, "where a woman could ride a bus or even drive a bus without having to tune out the constant staring and whispering of the dozens of sex-starved youth that swarmed around the Indian capital's streets..." (p. 242). Not only the youth, she might have added. Men of all ages in New Delhi subject women riding public buses or those waiting for transport on the roadside to intense unwarranted scrutiny. It is hazardous for women to travel alone late in the evening. In Beijing on the other hand, women rarely receive much unwelcome attention and travel fearlessly at the dead of night in most parts of the city.

8 Some pages of the book betray their origins as dispatches meant for specific newspapers, with their penchant for adjectives and "colour." Occasionally, some statements and figures that ought to have been footnoted are not, and the book's index is insufficient. However, this in no way detracts from the value of the book, which deserves to be read widely in India and China. (It would also be rewarding to revisit Vikram Seth's classic.) It is to be hoped that there will be more such writers and journalists from not only India but also other parts of South Asia, as well as from the Middle East, Central Asia, Africa, and Latin America, bringing their perspectives to bear on the study of the world's most populous country. There is, as Aiyar has noted elsewhere, room for a lot of other views on China. ${ }^{7}$ 


\section{NOTES}

1 Vikram Seth, in From Heaven Lake: Journeys Through Sinkiang and Tibet, 1983, writes on pages 104-105, "If I could be guaranteed the lucky place in the Indian sweepstakes that I at present occupy, there is no question as to what my answer would be; even if I were poorer than the average Chinese child, I would prefer to be born in India. But if I were born to the inhuman, dehumanizing misery in which the poorest third of our people live, to the squalor and despair and debility that is their life, my answer would not be the same."

2 Aravind Adiga, winner of the Man Booker Prize for fiction in 2008 for his novel The White Tiger (written, incidentally, in the form of letters addressed to the Chinese premier), says in an interview published on the following website, http://www.brooklynrail.org/2008/09/express/ india-a-view-from-below (last consulted 10 December 2009): "If you were a poor man you'd have to pick China over India any day because your kids have a better chance of being nourished if you're poor. Your wife is more likely to survive childbirth. You're likely to live longer. There are so many ways in which India's system fails horribly."

3 http://www.prembhatiatrust.com/awards.htm (last consulted 15 December 2009).

4 Friends of Tibet India, "Save The Hindu" Campaign, http://www.friendsoftibet.org/save/ (last consulted 15 December 2009).

5 As indicated in emails to this reviewer from the author and from the website's founder.

6 Michael Meyer, The Last Days of Old Beijing: Life in the Vanishing Backstreets of a City Transformed, New York, Walker and Company, 2008.

7 http://www.cityweekend.com.cn/beijing/articles/mag-bj/peeps/journalist-pallavi-aiyar-onindian-road-envy/ (last consulted 15 December 2009). 